\title{
Acute Toxicity Effect of Artemisia Afra Plant Extracts on the Liver, Kidney, Spleen and in Vivo Antimalarial Assay on Swiss Albino Mice
}

\author{
Ndeye Fatou Kane ${ }^{1, ~ *}$, Mutinda Cleophas Kyama ${ }^{2}$, Joseph Kangethe Nganga ${ }^{3}$, Ahmed Hassanali ${ }^{4}$, \\ Mouhamadou Diallo ${ }^{5}$, Francis Thuo Kimani ${ }^{6}$ \\ ${ }^{1}$ Department of Molecular Biology and Biotechnology, Pan African University Institute of Basic Sciences and Technology Innovation/ \\ JKUAT, Nairobi, Kenya \\ ${ }^{2}$ Department of Medical Laboratory Sciences, Jomo Kenyatta University of Agriculture \& Technology, Nairobi, Kenya \\ ${ }^{3}$ Biochemistry Department, Jomo Kenyatta University of Agriculture \& Technology, Nairobi, Kenya \\ ${ }^{4}$ Chemistry Department, Kenyatta University, Nairobi, Kenya \\ ${ }^{5}$ Department of Biology, Bacteriology \& Virology Laboratory, Cheikh Anta Diop University, Dakar, Senegal \\ ${ }^{6}$ Kenya Medical Research Institute (KEMRI), Nairobi, Kenya
}

\section{Email address:}

fatou.ndeye@students.jkuat.ac.ke (N. F. Kane),kcleophas@yahoo.com (M. C. Kyama), jnganga@jkuat.ac.ke (J. K. Nganga), ahmedhassanali786@gmail.com (A. Hassanali), misbax@gmail.com (M. Diallo), fkimani@kemri.org (F. T. Kimani)

${ }^{*}$ Corresponding author

\section{To cite this article:}

Ndeye Fatou Kane, Mutinda Cleophas Kyama, Joseph Kangethe Nganga, Ahmed Hassanali, Mouhamadou Diallo, Francis Thuo Kimani. Acute Toxicity Effect of Artemisia Afra Plant Extracts on the Liver, Kidney, Spleen and in Vivo Antimalarial Assay on Swiss Albino Mice. Advances in Bioscience and Bioengineering. Vol. 7, No. 4, 2019, pp. 64-71. doi: 10.11648/j.abb.20190704.12

Received: August 31, 2019; Accepted: September 21, 2019; Published: October 12, 2019

\begin{abstract}
Artemisia afra (Jacq. Ex. Wild), or "African Wormwood" belonging to the family of Astereaces and is widely used traditionally for health care in the eastern part of Africa with few research evidence substantiating its safety. The aim of this study was to investigate the safety of the ethanolic, dichloromethane, and hexanolic extracts of Artemisia afra by determining its pharmaco-toxicological effects after an acute oral administration in mice and to test also their in vivo antimalarial effects. Oral acute doses of Artemisia afra extracts were given to thirty mice at the doses of 1000,2000 and 2500 $\mathrm{mg} / \mathrm{kg}$ of body weight. The mice were then observed for fourteen days, toxicity signs, body weight, organs weight and biochemical parameters were checked. Four days peter's test was run on mice to determine the in vivo antimalarial activity of the plant extracts and the IC50 for each extract was determined. The results show few toxicity signs from the first two days after oral administration. There were no differences in organs weight and body weight for the experimental mice when compared to the control group. The level of alanine transaminase (ALT) and aspartate transaminase (AST) were found do not be statistically different from the control. The $\mathrm{LD}_{50}$ of the extracts was found to be greater than $2500 \mathrm{mg} / \mathrm{kg}$ of body weight. The results also showed a high antimalarial effect of the extracts when tested in vivo using Plasmodium Berghei Anka. In Conclusion Artemisia afra is a strong drug candidate for malaria with no toxic effects in high dosage.
\end{abstract}

Keywords: Oral Acute Toxicity, Medicinal Plant, Antimalarial Assay, Plasmodium Berghei Anka, Artemisia Afra, Biochemical Test

\section{Introduction}

A large percentage of the African population depends on medicinal plants for health care $[1,2]$. The World Health Organization (WHO) has recognized that $80 \%$ of the African population makes use of traditional medicine [3]. Artemisia afra is one of the most widely used herbs in traditional medicine. In recent years, it has gained significant attention from the scientific community. Studies have been conducted either to verify or to substantiate the traditional use of this 
herb. Furthermore, its use is also being investigated in the treatment of modern diseases like diabetes, cardiovascular diseases, cancer, and respiratory diseases [4]. In Africa, more than 2,000 plants have been identified and used as herbal medicines to treat several ailments, but very few of these plants have been screened for their safety and efficacy [5].

Artemisia afra grows naturally in a land with high altitude and it is distributed widely from South Africa to the Cap. The aqueous extract of $A$. afra has shown bronchodilator activity [6], as well as anti-histaminic and analgesic properties [7]. The ethanolic and dichloromethane extracts of the plant have been shown to have in vitro hypotensive and anti-tuberculosis effects, respectively [8]. Artemisia afra is also traditionally used in the treatment of malaria [9]. The aqueous, ethanolic and methanolic extracts have also shown high in vitro antimalarial effect $[9,10]$. Despite its multiple uses, very little is known about the toxicity of this plant [4] mostly, the toxicity when this plant is extracted using another solvent different from Water. Toxicity data are required to predict the safety associated before the use of medical products, it helps to decide whether a new drug should be adopted for clinical use or not [11]. This study aimed to investigate the toxicity of Artemisia afra plant when extracted with Ethanol, Dichloromethane, and Hexane at the same time to test their in vivo antimalarial effect using mice.

\section{Material and Methods}

\subsection{Plant Materials}

Arial part of Artemisia afra was collected from Rumonge in the Southern part of Burundi. The leaves were dried under shadow, grounded and sent to Nairobi under plastic bags. The phytosanitary certificate was provided to facilitate the transfer of the powdered leaves from Burundi to Kenya where the study was carried out.

\subsection{Extraction Process}

Powdered leaves of Artemisia afra was extracted with Dichloromethane; Ethanol and Hexane. The powder leaves were extracted with these three solvents in a flat bottom flask and sorely mixed on an orbital shaker. After gentle maceration for 48 hours, the extracts were filtered through a Whatman filter paper chart. The filtrate was concentrated under reduced pressure using rotary evaporator at $20 \mathrm{rpm}$ and $40^{\circ} \mathrm{C}$ bath temperature. Finally, concentrated extracts were collected in vials and placed on a water bath at $40^{\circ} \mathrm{C}$ to evaporate the remaining solvents and stored at room temperature for complete dryness.

\subsection{Ethical Approval}

This study was approved by the Animal Care and Use Committee (ACUC) of Kenya Medical Research Institute (KEMRI) to carry out that work. The mice were handled following the standard operating procedures guidelines for the care and use of laboratory animals.

\subsection{Experimentations on Animals}

The animals used in this study were provided by KEMRI animal laboratory facility. The animals were kept for 24hours in the acclimatization room before starting the experiment to avoid any stress. Thirty healthy adult male and female mice weighing between $20-22 \mathrm{~g}$ were used for the acute toxicity test. Mice were randomly assigned into 10 groups and were housed 3 animal per cages. Male and female were separated to avoid them to mate. The animals were kept in separate aluminium cages and provided with bedding of clean paddy husk. All animals had free access to water and food. The three extracts of Artemisia afra dissolved in 5\% DMSO and in PBS, were prepared for the acute toxicity test, three concentrations were made for each extract $2500 \mathrm{mg} / \mathrm{kg} ; 2000 \mathrm{mg} / \mathrm{kg} ; 1000 \mathrm{mg} / \mathrm{kg}$. Selection of doses was made based on the OECD guideline [12]. Mice were separated in 10 cages each with three individual per cage, 1 cage for control where the mice were inoculated with a mixture of phosphate buffer saline $1 \mathrm{X}$ with $5 \%$ DMSO and 9 others cages where every mice was inoculated with the extracts with only one single dose for each. The body weight of each mice was recorded before dosing. The first set, groups 2 to 4 received DCM extract with respectively three designated doses $(1000 \mathrm{mg} / \mathrm{kg}, 2000 \mathrm{mg} / \mathrm{kg} 2500 \mathrm{mg} / \mathrm{kg}$ of the formulation per body weight), the second set, groups 5 to 7 received ethanolic extract with respectively three designated doses $\quad(1000 \mathrm{mg} / \mathrm{kg}, \quad 2000 \mathrm{mg} / \mathrm{kg} \quad 2500 \mathrm{mg} / \mathrm{kg}$ of the formulation per body weight), and the last set, group 8 to 10 received hexanolic extract with respectively three designated doses $\quad(1000 \mathrm{mg} / \mathrm{kg}, \quad 2000 \mathrm{mg} / \mathrm{kg} \quad 2500 \mathrm{mg} / \mathrm{kg}$ of the formulation per body weight) to see a range of toxic effects and mortality rates in 48 hours observation.

After the single dose inoculation, mice were observed for 14 days toxicity signs and weight of animals were recorded every day. At the end of the experiment, mice were sacrificed using a $\mathrm{CO}_{2}$ chamber and put on dissecting board where the organs were collected and the blood was drawn by cardiac puncture and kept in a vacuum heparin tube.

The blood samples in the tubes were centrifuged at 2500 rpm for 15 minutes and the serum was drawn and transferred into other clean vials and kept at $-20^{\circ} \mathrm{C}$ until analysis for clinical chemistry measurements. The organs (Liver, Kidneys; and spleen) were collected and kept in phosphate buffered formalin solution for tissue processing, and the gross pathological observation of these organs was performed to check for any lesions.

\subsection{In Vivo Antimalarial Assay}

Fifty-six Swiss albinos' mice were used for in vivo antimalarial assays. The mice were infected with $P$. berghei anka and the assay was based on 4 days Peter test [13]. The parasite was provided by KEMRI and passage several times using donor's mice by intraperitoneal injection (IP) way. Briefly, an aliquot of $0.2 \mathrm{ml}$ of infected blood from donor's mice was used to infect the experimental mice through intraperitoneal injection. The mice were infected with the 
same amount of parasitized erythrocytes and divided randomly in a group of 4 individuals. Fourteen groups were made among which negative and positive group.

Two to 4 hours after infection (Day 0) mice were treated daily during 4 days with a single dose of test sample at a volume of $0.2 \mathrm{ml}$ by oral route. The positive group was treated with artemether $10 \mathrm{mg} / \mathrm{kg}$ of body weight dissolved in tween 80 and the negative group was given of saline buffer constitute with PBS buffer, DMSO (5\%) and $10 \%$ of tween 80. The remaining experimental groups were treated with Artemisia afra extracts. All the extracts were dissolved in DMSO and in Tween 80 and 4 dosages were made for DCM; hexanolic extracts $(400 \mathrm{mg} / \mathrm{kg}, 200 \mathrm{mg} / \mathrm{kg}, 100 \mathrm{mg} / \mathrm{kg}, 50$ $\mathrm{mg} / \mathrm{kg})$ and for ethanolic extracts $(200 \mathrm{mg} / \mathrm{kg}, 100 \mathrm{mg} / \mathrm{kg}, 50$ $\mathrm{mg} / \mathrm{kg}, 25 \mathrm{mg} / \mathrm{kg}$ ).

Parasitaemia was determined daily (24 hours interval) with a thin blood smear sampled from the tail and stain with $10 \%$ of Giemsa solution. At the end of the 4 days peter's test thin blood smear was similarly made ( $96 \mathrm{~h}$ post-infection) for all the animals and stained as described above. Parasitaemia was calculated under a microscope by counting four fields of approximately 200 erythrocytes per field. The difference between the mean value of the control group (taken as 100\%) and those of the experimental groups was calculated and expressed as the percentage of ChemoSuppression, according to the following formula [10]:

$$
\% \text { Chemo-Sup. }=[(\mathrm{A}-\mathrm{B}) / \mathrm{A}] \times 100
$$

$\mathrm{A}=$ Mean parasitaemia in the negative control group on day 4 .
$\mathrm{B}=$ Corresponding parasitaemia in the test group.

\subsection{Statistical Analysis}

All data were organized and analyzed using SPSS version 25 statistical software. The values of body and organ weight and the biochemical parameters were analyzed by SPSS and the results were expressed as $\mathrm{MEAN} \pm \mathrm{SE}$ (x) (standard error of the mean). Differences between the experimental and control groups were compared using one-way analysis of variance (ANOVA), followed by Dunnett's T-test to determine their level of significance. $\mathrm{P}<0.05$ were considered as statistically significant.

\section{Results}

\subsection{Effect of Acute Toxicity of Artemisia Afra Extracts on the Weight and Behaviour of the Mice}

After oral administration of the extracts, from the 30 mice used for acute toxicity test, only one died 24 hours after oral administration. That mouse belongs to the group treated with $2500 \mathrm{mg} / \mathrm{kg}$ of dichloromethane extract (DCM group1). Changes like loss of appetite, hypoactivity, lethargic, dizziness were observed at the dose of $2500 \mathrm{mg} / \mathrm{kg}$ and disappeared after the washout period after 2 days of observation.

Both the treated and control groups of mice had stable initial body weight during the first week and during the second week of the observation period, there is a proportional gain in their body weight (Figure 1, Figure 2, Figure 3).

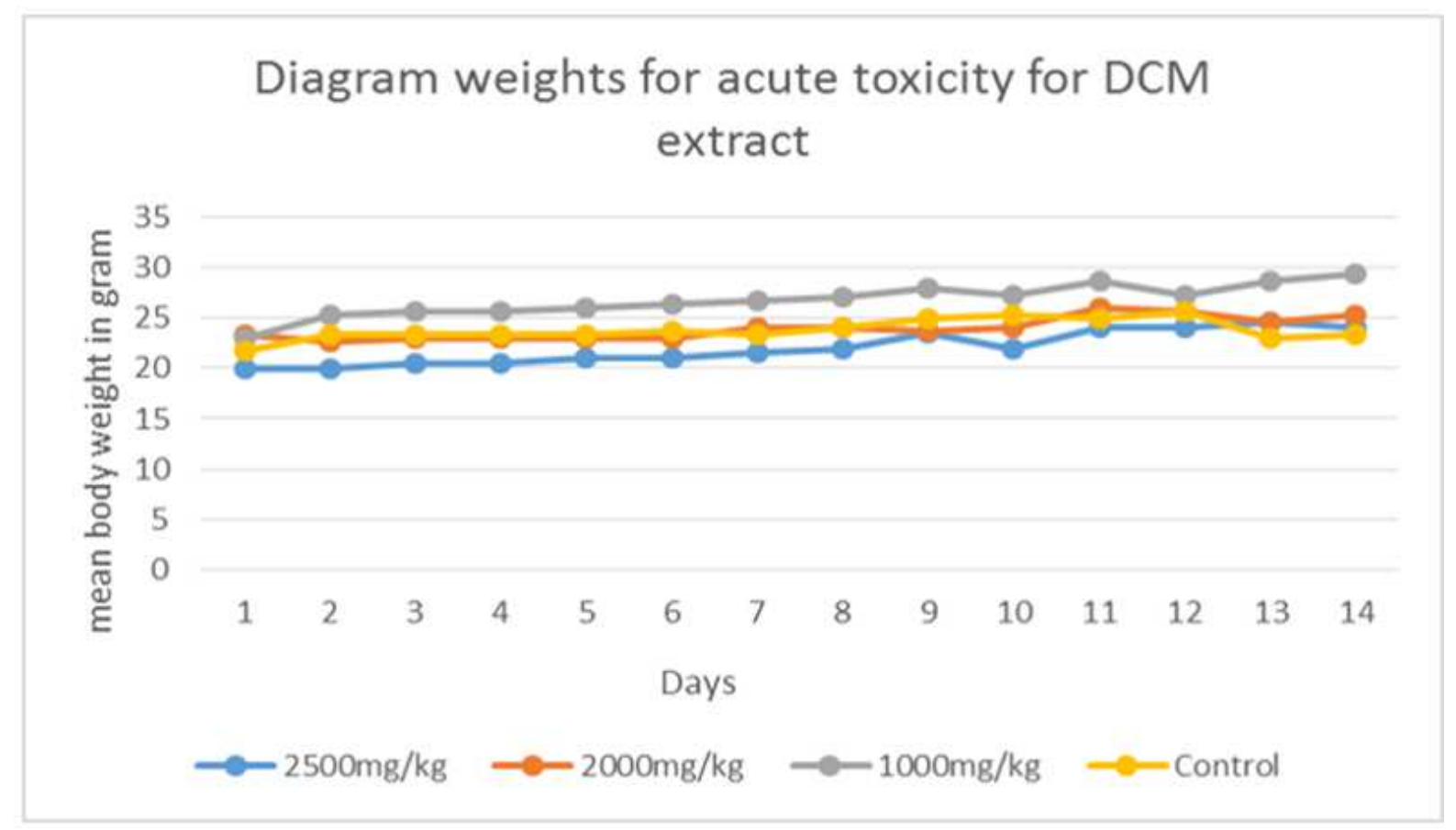

DCM: dichloromethane

Figure 1. Mean body weight change in mice treated with 2500mg/kg; 2000mg/kg, $1000 \mathrm{mg} / \mathrm{kg}$ DCM extracts one single dose. 


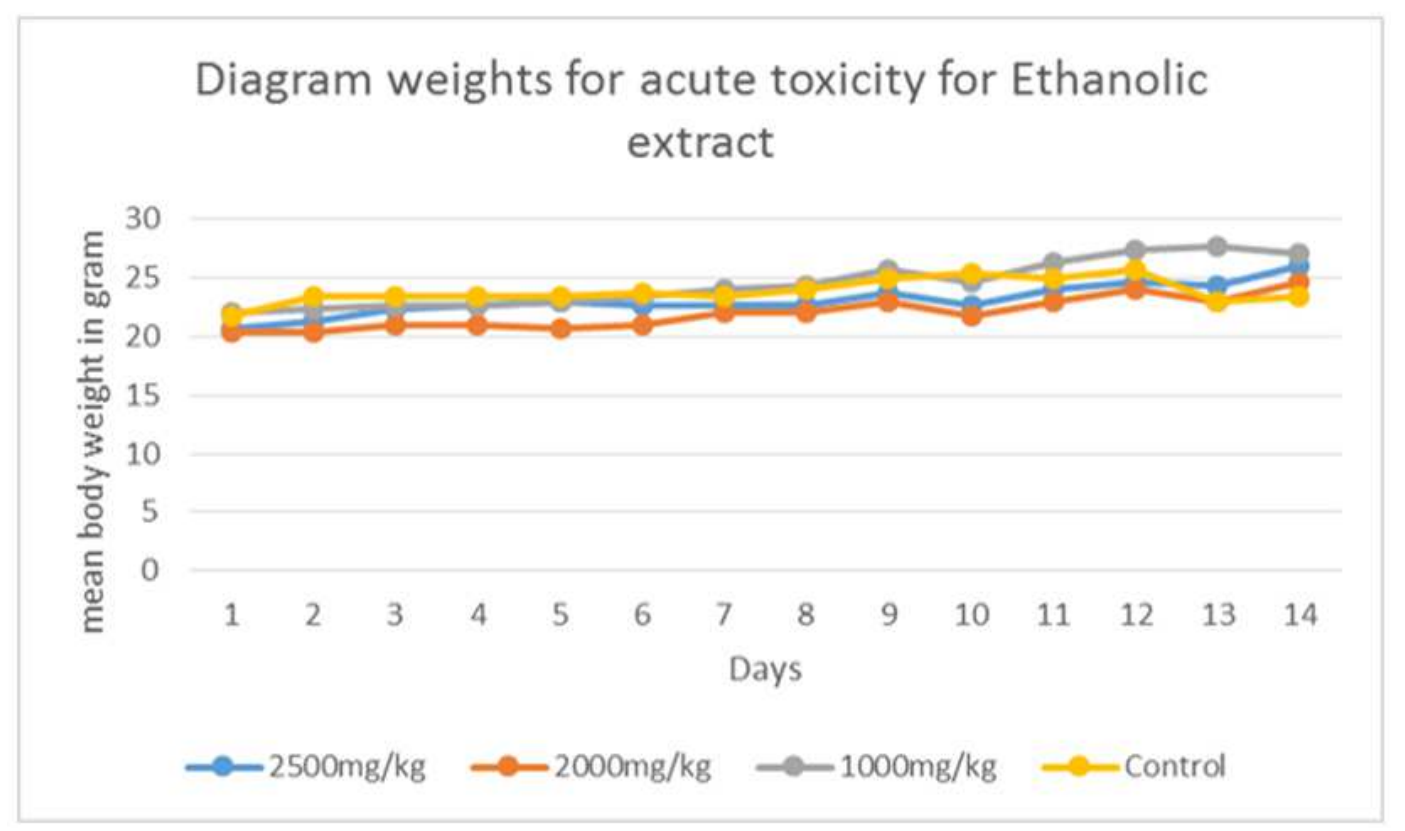

Figure 2. Mean body weight change in mice treated with 2500mg/kg; 2000mg/kg, 1000mg/kg Ethanolic extracts one single dose.

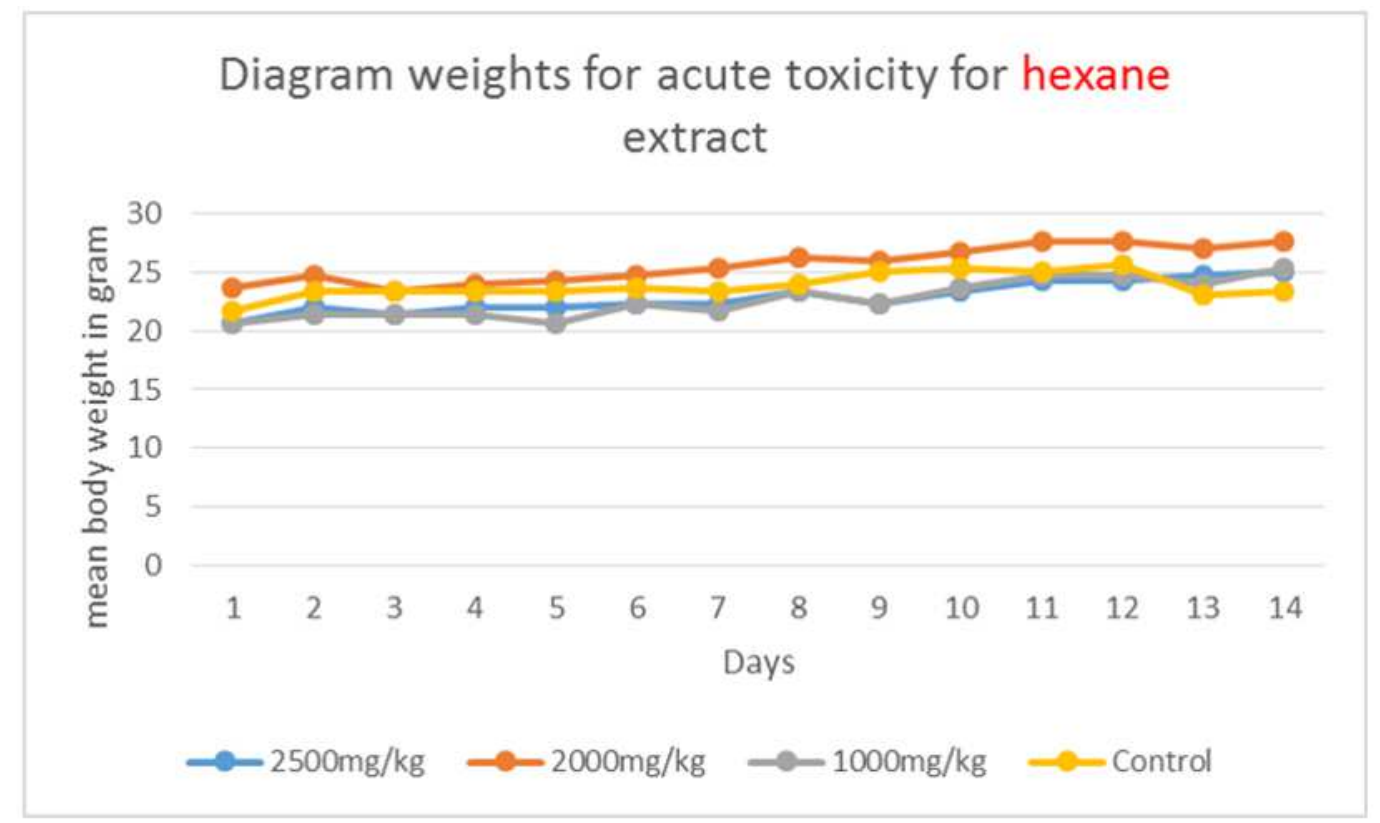

Figure 3. Mean body weight change in mice treated with $2500 \mathrm{mg} / \mathrm{kg} ; 2000 \mathrm{mg} / \mathrm{kg}, 1000 \mathrm{mg} / \mathrm{kg}$ Hexane extracts one single dose.

During the period of 14 days of acute toxicity test weight of animal was recorded daily and the statistical analysis of the weight between animal treated with extracts and the control showed some slight differences (Table 1).

Table 1. Mean body weight of mice treated with 3 extracts as compared to the control during 14days. Results presented as the mean of the body weight plus standard Error of the mean (P-value are in bracket).

\begin{tabular}{lllll}
\hline Groups & Doses mg/kg & DCM (Mean body weight+SE) & Ethanol (Mean body weight +SE) & Hexane (Mean body weight +SE) \\
\hline Group0 & Control & $23,8095 \pm, 28966$ & $23,8095 \pm, 28966$ & $23,8095 \pm, 28966$ \\
Group1 & 2500 & $22,0357 \pm, 43998^{* *}(, 008)$ & $23,095238 \pm(, 584)$ & $22,8571 \pm, 35414(, 287)$ \\
Group2 & 2000 & $23,9524 \pm, 28996(, 993)$ & $21,976190 \pm * *(, 010)$ & $25,6429 \pm, 41561^{* *}(, 006)$ \\
Group3 & 1000 & $26,7857 \pm, 44145^{* *}(, 000)$ & $24,500000 \pm(, 610)$ & $22,6667 \pm, 42510(, 150)$ \\
\hline
\end{tabular}

SE: standard error of the mean;

DCM: dichloromethane;

P-value 0.05 is considered as significant 
Mice treated with DCM extract the difference in body weight was significant when compared to the control in group 1 and group 3 . In group 1 their weight was slightly small compared to the control but for group 3 it was in contrast since showed progressive body weight gain (figure 1) in the same time the group3 had received the smallest doses and the group1 had received the highest doses.

For mice inoculated with ethanolic extract, there was a significant difference in body weight compared to the control. The mice in group 2, had a slight loss of their body weight and a similar observation was reported in those treated with hexanolic extract although there was an increase of their body weight for the mice in group2 treated with $2000 \mathrm{mg} / \mathrm{kg}$.

For the last group of mice inoculate with hexanolic extract, when we compared each group to the control a gain of weight was observed in group 2.

\subsection{Effect of Acute Toxicity of Artemisia afra Extracts on the Organs Weight of the Mice}

After the $14^{\text {th }}$ day, all the mice were sacrificed. Observation on the gross appearance of internal organs including liver, kidney, spleen and stomach of treated mice did not show any abnormal changes in texture, shape, size or colour in comparison to that of the control group. No lesion was noted in the internal organs in all groups.

Liver, kidney and spleen of each experimental group of mice were weight and compared to the control. A. afra extract did not produce any significant effect on the weight of the organs. The statistical analysis revealed that there were no significant differences between the organs of the mice inoculated with extracts (DCM, ETOH, and Hexanolic extracts) and the organs of the mice from control (Tables 24).

Table 2. Mean weight organs of mice treated with DCM extract as compared to the control (P-value in bracket).

\begin{tabular}{llll}
\hline \multirow{2}{*}{ Doses } & Mean weight \pm SE for DCM extract & & Spleen \\
\cline { 2 - 4 } & Liver &, $3500 \pm 01528$ &, $1000 \pm, 00000$ \\
\hline Control & $1,5400 \pm, 07572$ &, $4933 \pm, 05487(, 037)$ &, $1033 \pm, 01333(1,000)$ \\
$1000 \mathrm{mg} / \mathrm{kg}$ & $1,6267 \pm, 13383(1,000)$ &, $3000 \pm, 02000(, 978)$ &, $0933 \pm, 02404(1,000)$ \\
$2000 \mathrm{mg} / \mathrm{kg}$ & $1,3067 \pm, 08647(, 829)$ &, $3433 \pm, 00882(1,000)$ &, $1033 \pm, 00882(1,000)$ \\
$2500 \mathrm{mg} / \mathrm{kg}$ & $1,2533 \pm, 03756(, 586)$ & & Kidney \\
\hline
\end{tabular}

SE: standard error

DCM: dichloromethane

Table 3. Mean weight organs of mice treated with HEX extract as compared to the control (P-value in bracket).

\begin{tabular}{llll}
\hline \multirow{2}{*}{ Doses } & \multicolumn{2}{l}{ Mean weight \pm SE for hexane extract } & \\
\cline { 2 - 4 } & Liver & Kidney & Spleen \\
\hline Control & $1,5400 \pm, 07572$ &, $3500 \pm, 01528$ &, $1000 \pm, 00000$ \\
$1000 \mathrm{mg} / \mathrm{kg}$ & $1,2867 \pm, 06438(, 746)$ &, $2800 \pm, 01202(, 993)$ &, $0800 \pm, 01000(1,000)$ \\
$2000 \mathrm{mg} / \mathrm{kg}$ & $1,2800 \pm, 01732(, 715)$ &, $2800 \pm, 01764(, 442)$ &, $0967 \pm, 00333(1,000)$ \\
$2500 \mathrm{mg} / \mathrm{kg}$ & $1,1600 \pm, 06429(, 202)$ &, $2800 \pm, 02082(, 813)$ &, $1000 \pm, 00000(1,000)$ \\
\hline
\end{tabular}

SE: standard error

Table 4. Mean weight organs of mice treated with EtOH extract as compared to the control (P-value in bracket).

\begin{tabular}{|c|c|c|c|}
\hline \multirow{2}{*}{ Doses } & \multicolumn{3}{|c|}{ Mean weight \pm SE for Ethanolic extract } \\
\hline & Liver & Kidney & Spleen \\
\hline Control & $1,5400 \pm, 07572$ &, $3500 \pm, 01528$ &, $1000 \pm, 00000$ \\
\hline $2000 \mathrm{mg} / \mathrm{kg}$ & $1,1233 \pm, 12252(, 118)$ &, $3500 \pm, 03215(1,000)$ &, $0767 \pm, 02186(1,000)$ \\
\hline $2500 \mathrm{mg} / \mathrm{kg}$ & $1,3900 \pm, 09018(, 992)$ &, $3300 \pm, 01528(1,000)$ &, $1267 \pm, 03180(1,000)$ \\
\hline
\end{tabular}

EtOH: Ethanol

SE: standard error

\subsection{Effect of Acute Toxicity of Artemisia Afra Extracts in the Biochemical Parameters Compared to the Control Group}

AST and ALT level was tested in plasma of the mice treated with extracts and compared to the control to detect any sign of toxicity on the liver. When we compared the biochemical parameters between the experimental mice and the control, there were no significant changes for the ALT and AST level in all doses of Artemisia afra extracts (Dichloromethane, hexane, and ethanolic) (Table 5). 
Table 5. Effect of DCM, EtOH, and Hexane Extracts on AST and ALT biochemical parameters, mean of experimental groups compared to the control (Expressed in Mean $\pm S D E, P$-value in bracket).

\begin{tabular}{lllll}
\hline \multicolumn{1}{l}{ Liver Function Test (AST in $\boldsymbol{\mu} / \mathbf{l})$} & & & Hexane \\
\hline Groups & Doses $(\mathbf{m g} / \mathbf{k g})$ & DCM & Ethanol & $196,3333 \pm 25,89938$ \\
\hline Control & - & $196,3333 \pm 25,89938$ & $196,3333 \pm 25,89938$ & $422,3333 \pm 63,83(, 440)$ \\
Group1 & 1000 & $259,0000 \pm 19,07(0,852)$ & $189,0000 \pm 65,96(1,000)$ & $508,0000 \pm 122,40(, 667)$ \\
Group2 & 2000 & $206,6667 \pm 42,58(1,000)$ & $305,0000 \pm 57,422(, 906)$ & $370,3333 \pm 45,03(, 397)$ \\
Group3 & 25000 & $304,0000 \pm 66,39(, 951)$ & $264,6667 \pm 27,5095(, 901)$ & \\
\hline \multicolumn{5}{c}{} \\
\hline Liver Function Test (ALT in $\boldsymbol{\mu} / \mathbf{l})$ & & & \\
\hline Control & - & $33,2333 \pm 1,6835$ & $33,2333 \pm 1,6835$ & $33,2333 \pm 1,6835$ \\
Group1 & 1000 & $41,8000 \pm 6,23(0,975)$ & $45,2333 \pm 13,57(0,999)$ & $63,4000 \pm 3,43(, 055)$ \\
Group2 & 2000 & $34,6667 \pm 3,10(1,000)$ & $51,2000 \pm 13,55(, 974)$ & $119,0667 \pm 36,72(, 0715)$ \\
Group3 & 2500 & $37,0500 \pm 2,62(0,994)$ & $48,0667 \pm 9,71(0,944)$ & $79,2333 \pm 18,48(, 673)$ \\
\hline
\end{tabular}

\subsection{In Vivo Antimalarial Assay of Artemisia Afra Extracted with DCM, EtOH, and Hexane}

Antimalarial effects of extracts of Artemisia afra on Plasmodium berghei in mice are summarized in tables 6 and 7. The suppression of the Parasitaemia (chemo-suppression) and the ED50 were used as measured of efficacy. Four Dosages were used to do the in vivo antimalarial assay. Samples were categorized as highly active when chemosuppression was above $60 \%$ or moderately active between 30 and $60 \%$, but lowly active below $30 \%$. At the dosage of $200 \mathrm{mg} / \mathrm{kg}$ of body weight for all the different extracts, we got around the same percentage of suppression $(\mathrm{ETOH}$
61.64\%; DCM 63.82\%; and Hexane 66.89\%) all results showed a high suppression of the parasites. When dosage was decreased the parasitaemia changed as follows, at the dosage of $100 \mathrm{mg} / \mathrm{kg}$ EtOH extract were the most active and showed moderate suppression compared to the others with a percentage of chemo-suppression which is still high at $57.07 \%$ for ETOH extract; following by DCM extract $42.17 \%$ and come in last Hexane extract $32.19 \%$. The same observation was observed at the dosage of $50 \mathrm{mg} / \mathrm{kg}$ of body weight the activity is still moderate for the $A$. afra ethanolic and DCM extracts but low for the hexane extract.

Table 6. Effect of DCM, EtOH and Hexanolic extracts of Artemisia afra on P. Berghei infected mice.

\begin{tabular}{lllll}
\hline Dosage / \%Chemosup. & Dosage 1 200 $\mathbf{m g} / \mathbf{m l}$ & Dosage 2 100mg/ml & Dosage 3 50mg/ml & Dosage 4 25mg/ml \\
\hline DCM & $63.82 \% \pm 6.54 \%$ & $42.17 \% \pm 9.66$ & $32.26 \pm 9.25 \%$ & $5.84 \% \pm 2.20$ \\
ETOH & $61.64 \% \pm 6.04$ & $57.07 \% \pm 11.97$ & $50.52 \% \pm 7,93$ & $35.42 \% \pm 4.3$ \\
\hline & & & & \\
\hline Dosage & Dosage 1 400 $\mathbf{m g} / \mathbf{m l}$ & Dosage 2 200 $\mathbf{m g} / \mathbf{m l}$ & Dosage 3 100mg/ml & Dosage 4 50mg/ml \\
\hline Hexane & $73.23 \% \pm 13.52$ & $66.89 \% \pm 5.07$ & $32.19 \% \pm 23.34$ & $22.86 \% \pm 18.88$ \\
Positive control & $88.33 \%$ & & & \\
\hline
\end{tabular}

The ethanolic extract of $A$. afra has the highest in vivo antimalarial activity with the highest $\mathrm{ED} 50=6.43 \mathrm{mg} / \mathrm{ml}$ following by the DCM extract ED $50=11.99 \mathrm{mg} / \mathrm{ml}$ then came is last the hexanolic extract $\mathrm{ED} 50=14.79 \mathrm{mg} / \mathrm{ml}$.

Table 7. ED50 from in vivo antimalarial assay for DCM, ETOH and Hexanolic extracts of Artemisia afra collected from Burundi.

\begin{tabular}{llll}
\hline Afra extracts & Ethanolic & DCM & Hexane \\
\hline ED50 $(\mathrm{mg} / \mathrm{ml})$ & 6.43 & 11.99 & 14.79 \\
\hline
\end{tabular}

\section{Discussions}

Artemisia afra is widely used as a traditional medicinal plant in many countries e.g. South Africa [5] for its wild medicinal properties. Acute (single dose) toxicity was conducted in mice swiss albinos for a period of 14 days to determine the toxicity of the plant. Most studies have tested toxicity only on the aqueous extract. The toxicity of $A$. afra extracted with other solvents (DCM; ethanol, hexane...) needs to be investigated because having high antimalarial activities due to interest in the medicinal value of the plant. In this present study, the ethanolic, hexane, and DCM extract of A. afra were tested for their toxicity and also in vivo antimalarial activity. The result of the acute toxicity did not report mortality with single oral dose up to $2500 \mathrm{mg} / \mathrm{kg}$ body weight. Only one single mortality was recorded for the DCM extract at the dosage of $2500 \mathrm{mg} / \mathrm{kg}$ body weight. The present result, therefore, suggests that the oral $\mathrm{LD}_{50}$ of all the extracts are greater than $2500 \mathrm{mg} / \mathrm{kg}$. Others studies after an acute toxicity test have reported an $\mathrm{LD}_{50}$ more than $5000 \mathrm{mg} / \mathrm{kg}$ of body weight but for Aqueous extract of Artemisia afra [14] that showed that the aqueous extract is much safer. During the 14 days test, the body weight was recorded daily. Body weight changes are indicators of adverse side effects of drugs and chemicals $[15,16]$, as the animals that survive cannot lose more than $10 \%$ of the initial body weight [17]. An Increase of the body weight for all groups is observed during week 2 . The increment in body weight determines the positive health status of the animals [18]. However, differences between the experimental and control group were noted. A decrease of body weight was observed for the group of mice treated with DCM extract at the dosage of $2500 \mathrm{mg} / \mathrm{kg}$ and also for ETOH extract at $2000 \mathrm{mg} / \mathrm{kg}$ compared to the control, but for hexane extract 
of A. afra at the dosage of $2000 \mathrm{mg} / \mathrm{kg}$ of body weight there is a gain of weight compare to the control. For the other groups, the weight gain is not significantly different from that of the control group. Therefore, the overall weight gain in both treated and control mice might indicate a good health status of the experimental animals. Research done by Eshetu et al in 2016 [19], the same observation was done during an acute oral administration test of aqueous extract of Artemisia afra. For the weight of the organs, there are no significant differences between the experimental groups and the control. Organs weight is an index of swelling, atrophy or hypertrophy [20]. Comparison of organ weights between control and treated groups have conventionally been used to predict the toxic effects of test material [21-23] and help to know if the organs were exposed to injury or not. However, in the present study, there was no significant change in organ (liver, spleen, and kidney) weights and visual gross examination of the organs of both treated mice and the controls. These showed normal architecture, no color change and no morphological disturbances, indicating that the acute toxicity oral doses of $A$. afra extracts administered had no effect on the organs of the mice and was well tolerated.

ALT and AST biochemical test were evaluated using the plasma from the blood of the mice to obtain further toxicity related information, not detected by direct examination of organs and body weight analysis. No statistical differences were noted when we compare the experimental mice with the control, which suggested that the extracts have no effect on the liver function. Generally, liver cell damage is characterized by a rise in serum enzymes like AST, ALT, ALP, etc. [24, 25]. In our results AST is more expressed compare to ALT this is due to that AST is expressed in higher concentration in a number of tissues (liver, kidney, heart and pancreas) and it is released slowly compare to ALT [26]. Artemisia afra is a promising medicinal plant with a high antimalarial effect. Mostly the acute toxicity for $A$. afra plant is done for the aqueous extract it is also very important to check the toxicity of the plant extracts when others solvents are used for the extraction. The antimalarial effect is more important when the plant is extracted with others solvent for example with methanol or ethanol compare to when it is extracted with water because this solvents (methanol, ethanol) extract more bioactive compounds that may have medicinal importance. The problem using those solvents is they may have toxic effect why toxicity test is important to run for them.

The in vivo antimalarial assay of $A$. afra extracts $(\mathrm{EtOH}$, DCM and Hexanolic extracts) was found to have high activities. A. afra extracted with ethanolic had the highest activity, following the DCM extract then by the $A$. afra hexanolic extract. The results are in line with the study done by Gathirwa et al., who found a high chemo-suppression activity of $A$. afra plant extracted with $\mathrm{MeOH}$ during in vivo antimalarial activity with $P$. berghei anka [10]. This plant not only had a big antimalarial activity but also was found to inhibit rapid growing of Mycobacterium aurum and virulent Mycobacterium tuberculosis replication [27], to reduce also blood glucose and may have beneficial effects on complications of diabetes [28], and also to have potential anticancer properties [1].

\section{Conclusion}

Artemisia afra plant has a remarkable in vivo antimalarial activity. The $\mathrm{LD}_{50}$ after acute oral toxicity was greater than $2500 \mathrm{mg} / \mathrm{kg}$ of body weights. No significant changes in general behaviour and biochemical parameters, except a slight increase in AST activity. No significant changes were observed also in organ weights. In conclusion, findings suggest that $A$. afra extracts have a significant in vivo activity and are no toxic when given orally up to $2500 \mathrm{mg} / \mathrm{kg}$. This plant constitutes a great source to find new antimalarial compounds. Further studuies, however are required to study the safety of that plant during a sub-chronic test.

\section{Acknowledgements}

This work was supported by African Union through the program of $\mathrm{PhD}$ in Pan African University Institute of Basic Sciences and Technology Innovations.

\section{Conflict of Interest}

The author declare no conflict of interest.

\section{Ethical Considerations}

This study was approved by the Animal Care and Use Committee (ACUC) of Kenya Medical Research Institute (KEMRI) to carry out that work.

\section{Funding/Support}

This work was funding by African Union through Pan African University.

\section{References}

[1] Spies L, Koekemoer TC, Sowemimo AA, Goosen ED, Van de Venter M. Caspase-dependent apoptosis is induced by Artemisia afra Jacq. Ex Willd in a mitochondria-dependent manner after G2/M arrest. South African Journal of Botany; 2013; 84 104-109.

[2] Jamshidi-Kia F, Lorigooini Z, Amini-Khoei H. Medicinal plants: Past history and future perspective. Journal of Herbmed Pharmacology. 2018; 7 (1): 1-7.

[3] Gurib-Fakim, A.,. Medicinal plants: traditions of yesterday and drugs of tomorrow. Molecular Aspects of Medicine 2006, $27,1-93$.

[4] Gayathri V. Patil, Sujata K. Dass and Ramesh Chandra," Artemisia afra and Modern Diseases" Journal of Pharmacogenomics \& Pharmacoproteomics, 2011, 2: 3 DOI: 10.4172/2153-0645.1000105. 
[5] Liu, N. Q., Van der Kooy, F., Verpoorte, R.,. Artemisia afra: a potential flagship for African medicinal plants? South African Journal of Botany 2009; 75, 185-195.

[6] Harris, L., An evaluation of the bronchodilator properties of Mentha Longifolia and Artemisia afra, traditional medicinal plants used in the Western Cape M. Thesis, Discipline of pharmacology. School of pharmacy, University of the Western Cape. Bellville. 2002.

[7] Cunningham, A., et al., Zulu Medicinal Plants: An inventory. South Africa, University of Natal press. Scottsville, 1996; p: 327.

[8] MRC and S. Health info, Traditional medicines database: www.mrc.ac.za/Tramed3/Tramed3PlantPharmacologyDetails. 2004.

[9] Moges, K., et al., In Vitro Test of Five Ethiopian Medicinal Plants for Antimalarial activity against plasmodium Falciparum. Ethiopian J. Sci 1998; 21 (1): p. 81-89.

[10] James W. Gathirwa, Geoffrey M. Rukunga, Eliud N. M. Njagi, Sabah A. Omar, Anastasia N. Guantai, Charles N. Muthaura, Peter G. Mwitari, Cecilia W. Kimani, Peter G. Kirira, Festus M. Tolo, Teresia N. Ndunda, Isaiah O. Ndiege, In vitro anti-plasmodial and in vivo anti-malarial activity of some plants traditionally used for the treatment of malaria by the Meru community in Kenya; The Japanese Society of Pharmacognosy and Springer 2007; DOI: 10.1007/s11418007-0140-0.

[11] Fennell, C. W., et al., Assessing African medicinal plants for efficacy and safety: pharmacological screening and Toxicology. Journal of Ethno-pharmacology. 2004; 94 (2-3): p. 205-217.

[12] OECD Guideline for testing of chemicals; "Acute oral toxicity-Acute toxic class method", 2001, PDF available at https://ntp.niehs.nih.gov/iccvam/suppdocs/feddocs/oecd/oecd gl423.pdf

[13] Peters W, Portus JH, Robinson BL. 'The chemotherapy of rodent malaria, XXII. The value of drug-resistant strains of Plasmodium berghei in screening for blood schizontocidal activity." Ann Trop Med Parasitol, 1975; 69: 155-171

[14] Idris Ahmed Issa and Mohammed Hussen Bule. Hypoglycemic Effect of Aqueous and Methanolic Extract of Artemisia afraon Alloxan Induced Diabetic Swiss Albino Mice. Journal Evid Based Complement Alternat Med. 2015; 2015: 752486.

[15] Hilaly, J. E., Z. H. Israeli, and B. Lyoussi, Acute and chronic toxicological studies of Ajuga Ivain experimental animals. J. Ethno-pharmacology, 2004; 91: p. 43-50.

[16] Hermine Boukeng Jatsa, Joseph Bertin Kadji Fassi, Mérimé Christian Kenfack, Nestor Gipwe Feussom, Mireille Poumeni Kameni, Nadège Distele Simo, Emilienne Tienga Nkondo, Alain Bertrand Dongmo, Louis-Albert Tchuem Tchuent.' Acute and sub-chronic oral toxicity studies of the leaves aqueous extract of Clerodendrum umbellatum Poir. on mice'. American journal of physiology, biochemistry and pharmacology, 2018 vol 7, no. 2, page 75-85 10.5455

[17] Teo S, Stirling D, Thomas S, Hoberman A, Kiorpes A, Khetani V. A 90-day oral gavage toxicity study of Dmethylphenidate and D, L-methylphenidate in Sprague Dawley rats. Toxicology 2002; 179: 183-196.
[18] Heywood, Long term toxicity. In: Balls M, Riddell RJ, and Worden AN, editors, Animals and alternatives in toxicity testing, London: Academic Press. 1983; p. 79-89.

[19] Nikodimos Eshetu, Mekbeb Afework, Eyasu Makonnen, Asfaw Debella, Wondwossen Ergete, Tesfaye Tolesssa. "Evaluation of the Acute and Sub-chronic Toxic Effects of Aqueous Leaf Extracts of Artemisia afra on Liver, Kidney and Some Blood Parameters in Wistar Rats" Advances in Bioscience and Bioengineering 2016; 1 (1): 1-9.

[20] Amresh G, Singh PN, Rao CV (2008). Toxicological screening of traditional medicine Laghupatha (Cissampelos pareira) in experimental animals. Journal of Ethnopharmacology 2008; 116: 454-460.

[21] Nisha A, Muthukumar SP, Venkateswaran G. Safety evaluation of arachidonic acid rich Mortierella Alpina biomass in albino rats-a subchronic study. Regulatory Toxicology and Pharmacology 2009; 53: 186-194.

[22] Pfeiffer CJ. A mathematical evaluation of the thymic weight parameter. Toxicology and Applied Pharmacology 1968; 13: 220-227.

[23] Aniekan Imo Peter, Edwin CS Naidu, Edidiong Akang, Oluwatosin O Ogedengbe, Ugochukwu Offor, Sanjeev Rambharose, Rahul Kalhapure, Anil Chuturgoon, Thirumala Govender, and Onyemaechi O Azu. 'Investigating Organ Toxicity Profile of Tenofovir and Tenofovir Nanoparticle on the Liver and Kidney: Experimental Animal Study'. Toxicol Res. 2018 Jul; 34 (3): 221-229. Published online 2018 Jul 15. doi: 10.5487/TR.2018.34.3.221.

[24] Brautbar N, Williams IIJ. Industrial solvents and liver toxicity: risk assessment, risk factors and mechanisms. International Journal of Hygiene and Environmental Health 2002; 205: 479-491.

[25] Kwo, Paul Y MD, FACG, FAASLD; Cohen, Stanley M MD, FACG, FAASLD; Lim, Joseph K MD, FACG, FAASLD.' ACG Clinical Guideline: Evaluation of Abnormal Liver Chemistries' American Journal of Gastroenterology: January 2017 - Volume 112 - Issue 1 - p 18-35. doi: 10.1038/ajg.2016.517

[26] S. Chanda, J. Parekh, Y. Vaghasiya, R. Dave, Y. Baravalia and R. Nair, medicinal plants - from traditional use to toxicity assessment: a review, international journal of pharmaceutical sciences and research, 2017.

[27] Siyabulela Nutella, Pete Smitha, Lungile Matikab, James Mukunda, Hiram Arends, Nasiema Allieb, D. Mark Estes, Wilfred Mabuselae, Peter Folba, Lafras Steyn, Quinton Johnson, William R. Folk, James Synced, e, and Muazzam Jacobs, " efficacy of Artemisia afra phytotherapy in experimental tuberculosis", Elsevier Tuberculosis (Edinb). 2009 December; 89 (Suppl 1): S33-S40. doi: 10.1016/S14729792(09)70009-5.

[28] Idris Ahmed Issa and Mohammed Hussein Bule," Hypoglycemic Effect of Aqueous and Methanolic Extract of Artemisia afra on Alloxan-Induced Diabetic Swiss Albino Mice", Hindawi Publishing Corporation Evidence-Based Complementary and Alternative Medicine Volume 2015, Article ID 752486, 5 pages http://dx.doi.org/10.1155/2015/752486. 